\title{
ENGAGEMENT IN SOCIAL MOVEMENTS AND THE FIGHT FOR JUSTICE: A STUDY ON THE NARRATIVES OF BLACK MOTHERS
}

\section{O ENGAJAMENTO EM MOVIMENTOS SOCIAIS E A LUTA POR JUSTIÇA: UM ESTUDO SOBRE AS NARRATIVAS DE MÃES NEGRAS}

\author{
Etyelle Pinheiro de Araújo* \\ Liana de Andrade Biar* \\ Liliana Cabral Bastos ${ }^{* * *}$
}

\begin{abstract}
This article discusses the narrative practices of a Brazilian social movement whose members are the mothers and relatives of young people victimized by police raids into Rio de Janeiro's favelas. By analysing the narratives produced by activists, we explore how grief is converted into political fight. As we look into how mothers intertwine their individual pain with political activism, we examine (i) how emotions and suffering are organized in their narratives; and (ii) what discursive strategies are used in the process. Data was generated during public demonstrations, and the analysis suggests that it is by turning the pain of a losing a child into political insurgence that mothers narratively organize their emotions. As stories get told, events surrounding the murders are recontextualized and experiences are collectivized. Mothers' stories become narratives of resistance, which oppose institutional racism, but also narratives of re-existence (SOUZA, 2009), which recast the deaths of their children as an effect of a necropolitical logic of state organization.
\end{abstract}

Keywords: narrative analysis; grief; resistance.

\section{RESUMO}

$\mathrm{O}$ artigo se debruça sobre práticas narrativas de um movimento social formado por mães e outros familiares de jovens vítimas de incursões policiais em favelas do Rio de Janeiro. A partir da análise das narrativas de seus membros, a pesquisa tem como objetivo compreender como

* Pontifícia Universidade Católica do Rio de Janeiro, PUC-RJ, Rio de Janeiro, RJ, Brasil. etyelle. araujo@gmail.com

Orcid: https://orcid.org/0000-0003-4981-5027

** Pontifícia Universidade Católica do Rio de Janeiro, PUC-RJ, Rio de Janeiro, RJ, Brasil. lianabiar@ gmail.com

Orcid: https://orcid.org/0000-0002-8673-8668

*** Pontifícia Universidade Católica do Rio de Janeiro, PUC-RJ, Rio de Janeiro, RJ, Brasil. lilianacbastos@gmail.com

Orcid: https://orcid.org/0000-0003-2401-3060 
se dá a transformação do luto em luta, isto é, examinar como as mães articulam sofrimento pessoal e ativismo político, o que inclui a análise de: i) como emoções e sofrimento são organizados nas narrativas dessas mulheres; ii) que mecanismos discursivos são utilizados nessa articulação. Os dados foram gerados em protestos públicos e a análise sugere que é transformando a dor da perda de um filho em revolta que as mães organizam narrativamente suas emoções. Tal organização se dá por meio da racionalização dos eventos que compõem o cenário do assassinato; e da coletivização da experiência. Com esses movimentos discursivos, as histórias das mães se configuram em narrativas de resistência ao racismo institucional e também de reexistência (SOUZA, 2009), na medida em que redescrevem a morte de seus filhos como parte da lógica de atuação necropolítica do Estado.

Palavras-chave: Análise de Narrativa; luto; resistência.

\section{INTRODUCTION ${ }^{1}$}

Every year, thousands of people are fatally shot by the Rio de Janeiro military police during operations conducted in favelas. Such is the barbaric fallout of the public security policies which, under the guise of a so-called "war on drugs", extensively promote direct conflict with members of the drug-trafficking circuit in order to apprehend individuals and collect weapons, money, and narcotics. Former judge Maria Lúcia Karam (2015) argues that this putative "war on drugs" targets carefully selected groups, namely, small-scale drug producers, sellers and users, positioned at the economically vulnerable bottom of the global drug market.

Recurring local, head-on confrontation produces disastrous consequences. In the first quarter of 2020 alone, 435 people were killed by the civil and/or military police in the state of Rio de Janeiro-the highest rate in 21 years ${ }^{2}$. Around $70 \%$ of the victims were young black men, most with no participation in illegal drug commerce. While the number of deaths caused by state agents continues to rise steadily $^{3}$, the contemporary surge in ultra-conservative ideologies, which has reshaped both state and national politics, ensures that such operations remain legitimized by political and judicial institutions, as well as by more conservative segments of society. At present, this constitutes one of the main obstacles to the

1. The authors would like to thank the Brazilian National Council for Scientific and Technological Development $(\mathrm{CNP} q)$ for all support from the Research Grant for Liliana Cabral Bastos and Liana de Andrade Biar as well as from the PhD Scholarship for Etyelle Pinheiro de Araújo.

2. See $<$ https://brasil.estadao.com.br/noticias/rio-de-janeiro,com-434-mortes-letalidade-policial-norio-no-1-trimestre-de-2019-e-a-maior-em-21-anos,70002827768>

3. In 2017, in the state of Rio de Janeiro, 1.227 deaths were prompted by the intervention of security agents. In May 2020, as we begin to write this text, the number of civilian casualties stands at 751 . More information can be found at the Institute of Public Security: https://www.ispvisualizacao. rj.gov.br:4434/ 
enforcement of the fundamental human rights of a growing number of subjects (FACCHINI \& SÍVORI, 2017).

From a legal standpoint, the aforementioned deaths are treated as cases of "resistance to authority" ("autos de resistência"), or as "legal deaths" ${ }^{4}$. They are described in Article 121, c/c, 73, II of the Brazilian Criminal Code, where they are characterized-and authorized-as executions prompted by resistance to police authority. To put it differently, they are viewed as a form of self-defense during conflicts.

Legal proceedings follow a well-known script. First, the police officers involved in the operation file a Police Report ("Registro de Ocorrência"), a document which classifies the victim's death as a homicide prompted by opposition to police intervention. Then, a Police Investigation ("Inquérito Policial") is installed, and a series of procedures are established which allow the Civil Police Station and the Prosecution Office to examine relevant facts. At this juncture, if the investigation reveals that the police officer acted in self-defense (which nearly always happens), the public prosecutor can officially request that the case be shelved, call for new investigative procedures, or, should any doubt remain, file an information against the police officers for murder. The information, however, must still be accepted by a judge. As a rule, very few cases are officially presented in the form of informations to the Prosecution Office and subsequently proceed along the legal circuit. The system is notoriously slow and many of the required protocols are not fully complied with.

This paper focuses on a relevant, but often overlooked component of this complex machinery: the mothers and relatives of individuals victimized in cases of alleged resistance to authority. Through the creation of a social movement called the Rede de Comunidades e Movimentos contra a Violência (Network of Communities and Movements against Violence) (henceforth Rede), these people have engaged in a ceaseless fight for justice. In general, they pressure Public Prosecutors and Police Stations into ensuring that investigations will not stall. To do so, they must prove that the victims were not guilty; i.e., they must antagonize the police's account of the event,

4. The legal notion of "resistance to authority" was introduced during the Military Dictatorship to justify the apprehension of police officers caught in the act of committing murder. The official nomenclature was altered twice: first in 2011, to "homicides prompted by police intervention", and then in 2016, to "homicides prompted by opposition to police intervention". This happened as a result of the pressure exerted by social movements and international organizations, which filed lawsuits demanding that the concept of "resistance of authority" be suspended so that police abuse of power could be denounced. Changes in terminology, however, did not modify bureaucratic procedures. In the legal circuit, investigations of such crimes still proceed sluggishly, and the investigative procedures adopted are often insufficient. Most cases are ultimately shelved. 
documented in the Police Report, which claims that there was a conflict and that officers acted in self-defense. Family members often submit documents such as school reports and work cards or contracts to illustrate the character of their loved ones. Members of the Rede also organize and take place in public demonstrations in which mothers tell their own versions of the story to wider audiences. It is with the narrative performances of these mothers that this article is primarily concerned. By looking at discursive data, we aim to understand (i) how emotions and suffering are organized in such narratives; and (ii) what discursive mechanisms are used by mothers to turn the pain of grief into political insurgence. Before directly addressing these questions, though, we must briefly consider the racial component of the debate on public security policies, and we must further describe the Rede within which such narratives emerge ${ }^{5}$.

\section{NECROPOLITICS AND THE RACIAL DIMENSION OF THE DEBATE ON PUBLIC SECURITY}

While waging its reputed "war on drugs", the Brazilian State has historically relied on firepower to assert its sovereignty over drug dealers. In this context, state sovereignty takes the shape of what political scientist Achille Mbembe (2018) termed necropolitics-a form of control based on establishing who lives and who dies. Quite literally, in our research context, firearms are used to promote the destruction of certain segments of the population. Mbembe's discussion lays emphasis on how "the state of exception and the relationship of enmity have become the normative basis of the right to kill." The author, who examines how power "appeals to exception, emergency, and a fictionalized notion of the enemy" to justify extermination, looks into "those figures of sovereignty whose central project is not the struggle for autonomy, but the generalized instrumentalization of human existence and the material destruction of human bodies and populations" (2018, p. 127).

As we resort to the notion of necropolitics to inspect Rio de Janeiro's "war on drugs", key questions arise. What lives are recognized as lives in Brazilian societyi.e., to echo philosopher Judith Butler $(2015 ; 2020)$, what lives can be grieved when lost? How do processes of humanization and dehumanization define what lives can be considered as such and what lives cannot be publicly mourned? Butler

5. The authors would like to thank Robledo Neves Cabral Filho for his efforts on the English version of this paper. 
$(2015$; 2020) sustains that the ability to recognize and distinguish between lives partially depends on whether such lives are produced in accordance with socially established norms. The frames offered by the norm allow us to determine what lives can be understood as such. When warlike police operations are conducted during school hours, for instance, the State-the institution which commands and deploys police force-decides who gets to live and who must die. Considering that approximately $70 \%$ of the individuals killed by the military police in the state of Rio de Janeiro during the timespan covered by this study are black ${ }^{6}$, it seems reasonable to conclude that black lives are not seen as valid. They exist outside the socially proposed frames.

There are different ways to analyse state-sponsored necropolitics. Here, in particular, we would like to focus on the history of racial relations in Brazil, a country where the racial debate suffers continuous attempts at erasure. The lingering myth of "racial democracy" posits that all Brazilians are the same and that black people, descendants of enslaved individuals, have been fully integrated into our post-abolition society. At the same time, a silent form of racism continues to confine black populations to places of subordination (TELLES, 2004; WINANT, 2001; GONZALEZ, 1982; NASCIMENTO, 1978) - to positions such as students, workers, or criminals. In Brazil, racism can be said to assert itself through its own denial (GOMES, 2012); in other words, it is the very fact that racism is made invisible (especially by white people) that undermines productive discussion and hinders the adoption of effective counter-measures. Brazilian racism is both structural, insofar as it keeps black people away from most political and social structures, and institutional, i.e., translated into everyday discrepancies in the labor market, the educational circuit, the criminal justice system etc. Both structural and institutional racism largely favor whiteness (KILOMBA, [2008] 2019).

Institutionalized racism reveals the position black people are expected to occupy in the normative social grammar. They must not take part in decision-making, but suffer the consequences of decisions made by others. This is a deep-seated principle in the Brazilian criminal justice system, "which-since the early days of Brazilian society, when African peoples were enslaved-identifies black populations as requiring violent surveillance" (SINHORETTO \& MORAIS, 2018, p. 21). More often than not, the system legitimizes the death of civilians by acquitting police officers who commit crimes. The sheer number of unsolved and shelved cases

6. "Out of the 1.275 victims of homicide prompted by police intervention between 2010 and 2013 in the city of Rio de Janeiro, 99.5\% were men, $79 \%$ were black and $75 \%$ were between 15 and 29 years old" (Amnesty International, 2015). 
of homicide prompted by "opposition to police intervention" suggests not that individual police officers may act unduly, but that there is "a standard of police work which, more than simply arbitrary, remains insulated in its warlike nature, out of touch with society itself and with other sectors of public administration" (CERQUEIRA et al., 2017, p. 30). In short, violence against black populations can be seen as the upshot of institutionalized racism, which, in turn and retroactively, protects acts of racism (GONZALEZ, 1982). In the next section, we focus on one of the social movements which, in Rio de Janeiro, strongly oppose this status quo.

\section{THE REDE DE COMUNIDADES E MOVIMENTOS CONTRA A VIOLÊNCIA AND THE ENGAGEMENT OF FAMILY MEMBERS IN FORMS OF RESISTANCE}

The Rede de Comunidades e Movimentos contra a Violência is a social movement which offers legal and emotional support to the relatives-chiefly, the mothers-of young black men and women victimized by police violence. The movement also organizes public demonstrations to denounce episodes of police brutality and demand more efficiency and accountability on the part of authorities during investigations. Born in 2014 through the concerted efforts of residents of many of Rio de Janeiro's favelas, the initiative is a direct response to a series of episodes of police brutality, including the Borel and Vigário Geral massacres ${ }^{7}$.

From a theoretical viewpoint, the Rede can be understood as a network formed by mothers whose children were victims of police brutality and by activists from various social movements. Like the network organizations investigated by Scherer-Warren (1999), the Rede is predicated on a series of collective, solidary and collaborative strategies, and mothers rely on the support offered by activists to engender a persistent form of group activism which often extends across years, as family members whose cases have already been shelved often continue to participate in the fight alongside others. The Rede allows individuals to reconstitute themselves as political subjects in pursuit of social transformation (TOURAINE. 2007). Their individual struggles-i.e., their fight for justice in cases involving their own children-get collectivized as their priority becomes not only to solve all the cases which are still open, but to introduce systemic changes which may eradicate the problem altogether. The Rede can thus be seen as a social movement, as defined by Melucci (2001): a form of collective action undertaken by a group of activists

7. See the Vigário Geral Massacre, in 1993 (https://blogs.oglobo.globo.com/blog-do-acervo/post/ vigariogeral.html) and the Borel Massacre, in 2003 (https://anistia.org.br/noticias/chacina-borel15-anos-depoisninguem-foiresponsabilizado/) 
who, by relying on shared solidarity, manifest a conflict and seek to disrupt the system's limits of compatibility. This disruptive intent translates into participants' ongoing battle against the public security policies which daily produce an alarming number of victims.

Given the escalating number of murders prompted by opposition to police intervention in the city of Rio de Janeiro, the importance of movements such as the Rede cannot be overstated. As they pressure judicial organs such as the Prosecution Office and the Head of Civil Police, they attempt to expedite ongoing investigations and decry the participation of state agents in crimes. Members of the Rede have participated in countless "resistance to authority" hearings, and their fight has culminated in the enactment of a law which instituted the State Week of Victims of Violence in the State of Rio de Janeiro .

At present, the Rede relies on a relatively assiduous group-in terms of attendance to demonstrations and hearings-of about 15 relatives of victims of police violence. Their engagement in the movement epitomizes what sociologist J. M. Jasper calls a moral shock: an inclination towards political action as a result of visceral indignation provoked by specific events (JASPER, 1997, p. 106). According to Jasper, individuals can respond to episodes of violence or injustice in many different ways. While some may resign themselves to undesired change, especially when authorities do not yield to protests, others may engage in forms of political activity as their fear and anger spiral into indignation.

The Rede acts by confronting the very notion of state sovereignty. It does so by publicly accusing state agents of participation in crimes, as well as by stressing how the murders of innocent people have been mistakenly classified as acts of "selfdefense" (SANTIAGO, 2016). If resistance can be conceptualized as the ability to stir collective action, disturb or alter power arrangements, and promote structural change, then the Rede can be said to promote acts of resistance: overt attempts to modify existing dynamics or challenge power relations. As shown by sociologists Ewick and Silbey (2003), acts of resistance often originate "stories of resistance": widely circulating narratives which transcend their own chronological and spatial settings and further the collectivization and the dissemination of political activism. Stories of resistance, which often feature substantial socio-cultural knowledge of how power structures work, can thus be seen not as representations of occurred events, but as creative, political acts which call hegemony into question and demand structural change.

In this work, we argue that the narratives produced by mothers from the Rede can be understood as "stories of resistance", but also, and crucially, as acts of "re- 
existence". In her study on the literacy practices developed by activists from the Hip Hop movement in São Paulo, Ana Lúcia Silva e Souza (2009) introduces the notion of "re-existence" to designate cultural practices which not only resist, but re-signify or reinvent social uses of language and, by extension, reconfigure the status quo.

\section{THE POWER OF NARRATIVES IN THE ORGANIZATION OF HUMAN EXPERIENCE}

During public demonstrations in the streets of Rio de Janeiro, mothers of the victims of police violence tell their stories in a somewhat uniform fashion. Equipped with a microphone, they describe who their sons and daughters were, narrate how their murders took place, and explain how their own fight for justice has unfolded ever since. Our discussion of their stories will be informed by an understanding of narrative discourse as an organizer of human experience. In other words, we will approach narratives as discursive-interactional practices which, through an ongoing conversation with situated historical and cultural parameters, shape human experience and the memories of occurred events (BRUNER, 1997 [1990]). Rather than direct, transparent representations of past facts, we will view narratives as contextualized montages, produced in accordance with (or in defiance of) public expectations of coherence (LINDE, 1993). As individuals tell stories, they construct meanings about who they are, about their relationships with others, and about the world around them. As narrators performatively construct experiences and feelings, interlocutors become entangled in the narrated experience (MOITA LOPES, 2001; BASTOS, 2005; BASTOS \& BIAR, 2015).

The study of narrative discourse from a structural perspective was originated by William Labov (1972). Labov sees the narrative as a specific form of recapitulation, based on a sequence of clauses which describe tellable events, i.e., events which the narrator deems relevant. According to Labov, a canonical narrative must feature the following components: (i) an abstract, or summary, of the story; (ii) an orientation, which situates the story in space and time and introduces characters or participants; (iii) the complicating action, that is, a series of past-tense narrative clauses which describe the chronological sequence of events; (iv) the evaluation, which highlights and qualifies the point of the narrative, i.e., the reason why the story is being told (v) the resolution, which presents the outcome of the story, usually a consequence of the complicating actions; and (vi) the coda, which signals the end of the narrative and brings the conversation back to the present. The Labovian model has been heavily criticized for treating narratives as autonomous texts based on a sequence of syntactic units which recapitulate what happened (see discussion in LINDE, 1993; 
MISHLER, 2002; BASTOS, 2005). Yet, we believe that some of its elements, when used in tandem with other theories, can enrich narrative analysis. In this paper, our analysis will make use of the orientation, complicating action and evaluation categories. Our reading, however, will also be informed by theories which accentuate the interactional and sociocultural values underpinning narrative practice.

In her study of the connections between narrative and identity construction, Charlotte Linde argues that we communicate our experience to others by means of interactional units called life stories: narratives whose point displays extended reportability. A lifestory is the account of an event that is framed by its narrator as highly relevant, and which thus gets retold multiple times across the narrator's lifetime. With each repetition, elements of the story become increasingly interwoven until they are coherent with the construction of a public identity. According to Linde, the point of these narratives-which is necessarily evaluative-is "the understanding that the addressee must agree to about what the protagonist's actions mean-that is, the general, moral communication of what kind of a person this is and what kind of actions these are" $(1993$, p. 21). In this work, we attempt to contemplate the two evaluative dimensions described by Linde: one which points back to narrators themselves, to the kind of people they are; and one which indexes surrounding contexts and illustrates how the world is. As the next sections will demonstrate, evaluations (or positionings) about the world are crucial to an understanding of how the emotions and the suffering triggered by police brutality are organized in the narratives produced by mothers.

As a rule, "life stories" are evocative of culturally relevant biographical landmarks, such as professional transitions, weddings, diseases, tragedies, deaths etc. These stories can also include shorter fragments, which defy canonical expectations regarding narrative architecture. Georgakopolou (2006) refers to such fragments as small stories, and argues that they contribute to the identification not of coherent selves (woven across life stories), but of fragmented, multiple and transitory selves, defined in necessarily relational and transitory terms.

In the narrative performances (BAUMAN, 1986) produced in the political demonstrations, non-verbal actions also abound: emotional and bodily responses such as silent pauses, loud cries, and other expressions of anger and anguish. Sarbin (2002) writes that emotions have been decisively incorporated into the structure of such narratives, where they operate in tandem with verbal cues to produce interactional effects. In our specific case, they can help propagate solidarity across the social tissue, or they can allow narrators to elaborate on the experience of grief (FREIRE, 2011). By and large, such emotions can be approached as instruments 
which help catapult claims born of painful, individual experiences towards larger collective spheres (REZENDE \& COELHO, 2015).

Our corpus was generated through ethnographic work undertaken by the first author. It features recordings of demonstrations organized by the Rede and interviews with the mothers. In the analytical section, we examine what resources enable the death of a child to be constructed as a biographical landmark in the lives of the mothers who integrate the Rede. We also discuss how repeated retellings of these stories allow mothers to construct coherence around such events. Finally, we focus on the identity performances which emerge in the process.

The analysis subscribes to a qualitative interpretive research paradigm (DENZIN and LINCOLN, 2006). Our goal was to examine how, in decisionmaking processes as well as in the collective conduction of social action, forms of social organization become entwined with individual activities.

Given the first author's status as a member of the social movement under scrutiny, this project relied heavily on participant observation ${ }^{8}$. The other two authors engaged in close-up data analysis, which focused on the meanings related to the engagement of family members in the fight for justice. It follows that, in our analysis, an I-researcher and an I-activist are inextricably linked. Based on the idea that data does not speak for itself and does not describe a previously established reality, we understand that fieldwork-born knowledge is not neutral, but produced by researchers "who, through the lenses of their own identity and contextual conditions, look at their object from a specific perspective, and thus construct a narrative about the research field" (BASTOS \& BIAR 2015, p. 101).

\section{NARRATING THE FIGHT FOR JUSTICE}

In this article, our analysis is centered on a speech given by Anita, one of the mothers from the Rede, during an April 2017 demonstration. The protest, carried out in front of the Rio de Janeiro Prosecution Office, was meant to pressure governmental organs into hastening legal proceedings and addressing cases that had been lying stagnant for years. In her speech, Anita talks about her son, João, shot dead when he was $19^{9}$.

\footnotetext{
8. As a supporter of the Rede and a member of an alternative media collective, the first author obtained permission to record demonstrations and use data for the current research project.

9. In keeping with the guidelines offered by PUC-Rio's Ethics Committee, participants' names have been altered and references to their places of residence have been removed.
} 
Anita lives in a favela located in the North Zone of Rio de Janeiro. In 2014, her son was killed by a police officer from the local Pacifying Police Unit (UPP). João's death was framed as homicide prompted by opposition to police intervention, that is, as a case of "resistance to authority". Yet, there are glaring contradictions between officers' and witnesses' accounts of the episode. In the excerpts chosen for analysis, Anita underlines these contradictions and reports on her own fight for justice. At this point, we turn to Narrative Analysis and to the concept of emotion as an anthropological category to explore how the emotions and the suffering associated with death are narratively organized, as well as how specific discursive mechanisms operate by converting grief into insurgence. The analysis comprises two separate strands, each dedicated to one of these points.

\subsection{Broadening our understanding of the loss of a child}

In the following, strongly evaluative excerpt, Anita criticizes the racist practices adopted by the State in its "fight" against drugs. Her speech is interspersed by pauses, screams, and cries $^{10}$.

\section{Excerpt 1. "What happens is a war on poor people"}

\begin{tabular}{|c|c|c|}
\hline $\begin{array}{l}11 \\
12 \\
13 \\
14 \\
15 \\
16 \\
17\end{array}$ & Anita & $\begin{array}{l}\text { My name is Anita, I live in the X favela and I } \\
\text { am the mother of João da Silva. For some of you } \\
\text { here it might seem like you're hearing the same } \\
\text { story all the time, but this is what happens, our } \\
\text { children were murdered because of this RACIST } \\
\text { SYSTEM which says that favela residents, young } \\
\text { black poor people from marginalized communities, } \\
\text { HAVE to be MURDERED. And don't come with this } \\
\text { talk that this happens because of the "war on } \\
\text { drugs", because that's not true. We, who live in } \\
\text { favelas and have UNFAIRLY lost our children, we } \\
\text { know what happens is a war on poor people. They're } \\
\text { taking our children from us, and nobody CARES? } \\
\text { (3s). MY soN, he was murdered, he was shot in the } \\
\text { back at 19. He was totally defenseless. And } \\
\text { that's why I'm here today with these mothers, } \\
\text { these fathers, these family members }\end{array}$ \\
\hline
\end{tabular}

10. In the excerpt, one-second pauses are represented as (.), whereas longer pauses are represented according to their duration (2s). Upper-case letters were used to represent instances of phonetic emphasis, when mothers scream or cry. Transcription was an adaptation based on the model proposed by Loder (2008). 
Anita begins her narrative somewhat ritualistically, evoking a formula often used by members of the Rede. She mentions her name, her child's name, and the place where she lives: "My name is Anita, I live in the X favela, and I am the mother of João da Silva" (lines 1 to 3). In all the demonstrations attended by the first author of this study, relatives introduced themselves in this fashion. Indeed, during fieldwork, family members who had been in the Rede for longer could be seen teaching newcomers how to organize their speeches. Rituals like these are common in institutional contexts, where shaping narration reinforces collective cohesion and discursively produces an effect whereby all the narratives can be seen as similar items in a collection. Parallelisms identified across narratives underscore how the same tragedies reoccur and how the pain experienced by mothers becomes collectivized. Yet, despite such commonalities, a sense of agency on the part of family members is preserved by means of the elements which singularize each mother and child. Rhetorical rituals notwithstanding, there is an individual dimension to every story, and the specificity of each narrative is never disregarded.

Following her opening ritual, Anita directly addresses her audience-mostly composed of passersby. As she points out the very recurrence of narratives like hers, she non-canonically produces an abstract and a set of orientations which contextualize her story (lines 3 to 12). This contextualization, which accounts for most of the narrative, does not simply introduce elements that specify Anita's story; rather, it weaves a web of causalities which, it is suggested, culminated in João's death. Police brutality and the categorical genocide of black, favela-dwelling populations are constructed as effects of a "racist system". The narrator's evaluative constructions delegitimize the "official" justification offered by the police report for João's death, producing a sense of causality which is vital to the formulation of the narrative's point. Anita is not only narrating her son's death, but publicly denouncing a murderous political system.

This narrative structure-which employs an extended orientation not to situate events in space and time, but to introduce contextual elements which explain what happened-is another discursive resource commonly found in the stories told by Rede mothers. The connection drawn by Anita between the "fight against drugs" and the "murder of young black people" works as what Thompson (2001) calls a strategy of rationalization: a mechanism by which power relations are symbolically constructed as a chain of logically organized clauses. Here, for instance, the events which led to João's death are depicted as consequences of structural racism. The same phenomenon also helps construct what Linde (1993) terms narrative 
coherence. Linde writes that the ideas of sequentiality and causality woven in life stories do not mirror natural connections between life events-which can be seen as intrinsically opaque and meaningless. Instead, they index cultural and symbolic systems of intelligibility, known as "coherence systems", which ascribe social meaning to occurred events.

Coherence systems can include everyday explanations to everyday facts, but they can also, for instance, contain simplified versions of specialized theories. When Anita and other mothers blame the "racist system" and its war-on-drugs policy for the deaths of their children, they suspend naturalized discourses and introduce an alternative, semi-specialized explanation. The micro-episode of a favela killing is re-signified as the corollary of a macro, structurally racist context. More specifically, the State's murderous anti-drug policy is recast as a necropolitical practice (MBEMBE, 2018).

Once such relations have been constructed, Anita produces a new abstract. As a tearful question is introduced-"they're taking our children from us, and nobody CARES?" (lines 13 to 14)-, affect is embodied, empathy is triggered among audience members, and the debate becomes humanized. Calling on society to take public security policies into question, Anita decries how black people's deaths are contemptuously dismissed. She then produces a semi-specialized version of the debate on what lives can be considered meaningful, valuable, and grievable. In a high-engagement (TANNEN, 1989) performative act, Anita weeps. She concretely grieves the loss of her son, thus producing a multimodal discourse which rejects the banalization of his death.

As we have seen, the narrative's opening movements both summarize and contextualize the events in question. Anita then moves on to the main complicating action: João's murder. Hers is a small story (GEORGAKOPOULOU, 2006), centered on a couple of clauses ("MY SON, he was murdered, he was shot in the back") followed by an orientation ("at 19") and an evaluation ("he was totally defenseless"). Her verb choices and strategies of characterization add to the construction of the narrative's point, which is to dispute the official police version and reclaim João's innocence by stating that, if he was shot in the back and he was totally defenseless, the entire episode cannot have been one of resistance to authority. Anita then resorts to other evaluations, which allude to her own engagement, alongside other family members, in the fight for justice. This is found in lines 16 and 17: "And that's why I'm here today. With all these mothers, these fathers, these family members". João's unjustified murder is constructed as the moral shock which galvanized Anita 
into joining the Rede de Comunidades e Movimentos contra a Violência, as well as other social movements. By stressing the presence of other family members, Anita acknowledges the importance of the group in the quest for justice.

Narratives produced by other mothers engaged in the Rede also rationalize the events leading to their children's death by resorting to necropolitical coherence systems. That is the case of Cida, Higor Leandro's mother, whose narrative constructs meanings around her son's murder:

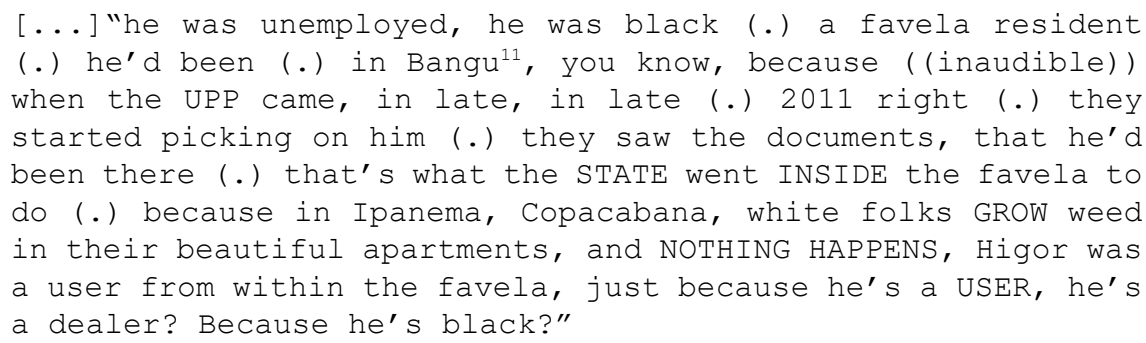

In this passage, whose rhetorical movements are similar to the ones found in Anita's narrative, Cida ascribes coherence to the events which culminated in Higor's death by arguing that they actualize the widespread discrimination against black individuals, former inmates, and favela residents. By means of a comparisonanother strategy of rationalization-, she denounces how police officers treat white drug users differently.

As we return to Anita's story, it becomes clear that, overall, she never ceases to mobilize emotions. In itself, the claim that her son was brutally shot in the back elicits a range of socially shared emotions: incredulity, suffering, sadness. The loss of a child is socially viewed as one of the most excruciating pains in the realm of personal experience, its occurrence in a context of violence and injustice intensifies the story's dramaticity. The repertoire of verbal and non-verbal cues which index such emotions includes instances of screaming and weeping, as well as modulations in Anita's voice. As she speaks, fellow members of the Rede embrace her and express their solidarity by chanting key-words like "Justice." All such evaluative resources act performatively and pressure the population into condemning the crimes committed by state agents.

The movement's motto - "From grief to fight" - is often spotted in signs carried by the mothers. In their narratives, emotions related to loss and suffering,

11. Bangú is the old name of a well known prison institution located in Rio de Janeiro - now known as Complexo Prisional de Gericinó. 
usually viewed as individual and passive, are reframed as forms of collective engagement. Two discursive movements play a key role in this process. The first one, as illustrated in this subsection, is the use of a specific narrative structure and of a multimodal repertoire of affective indexes. These instruments blur the distinctions between reason and emotion: as a banalized death finally gets publicly mourned, commotion and empathy are propagated, and a rationalization is proposed which extrapolates the event itself and positions it vis-à-vis broader social processes.

In the next subsection, we focus on another discursive movement which produces the same effect.

\subsection{Making the individual collective}

We have already characterized Anita's speech as a non-canonical narrative. As we have shown, little emphasis is placed on the narration of the life story itself, i.e., on the complicating actions related to João's murder or to the fight for justice. Anita's narrative magnifies not her own, personal episode, but the macrocontext which both exceeds and encompasses her individual experience. A bit more specifically, she constructs the micro-event of her son's murder as part (and consequence) of a macro-context of structural racism. There are only two moments in which Anita verbally highlights her individual experience:

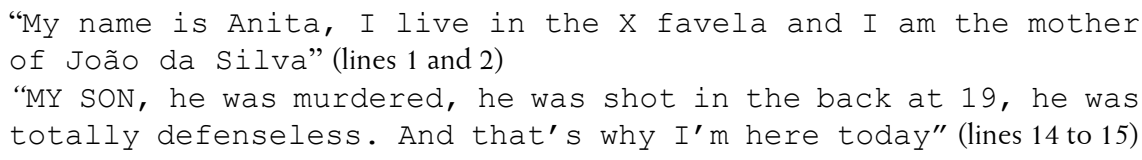

Anita's speech features several attempts to move beyond an individual scale and introduce a wider group of characters. This happens, for instance, in (emphasis added):

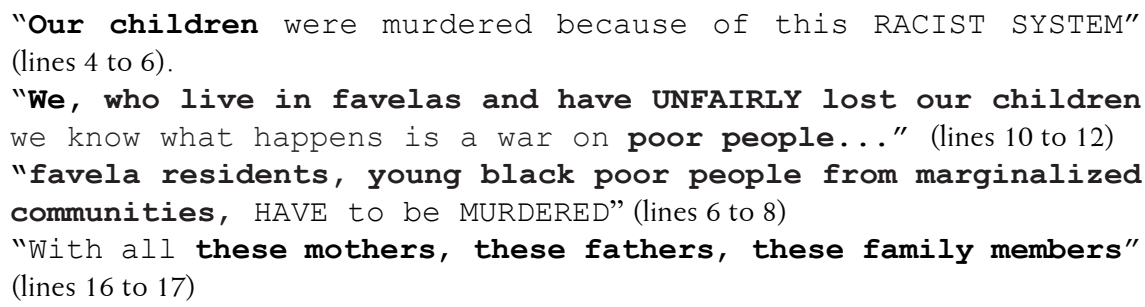

Generally speaking, the grammar of grief and suffering for the loss of a loved one mostly comprises passive and individual experiences. Through the use of plural 
forms and strategies of collectivization, however, Anita and the other members of the movement speak on behalf of all the black women and all the favela residents who have lost their relatives. As she constructs an idea of we-ness (POLLETTA \& JASPER, 2001), her pain gives rise to insurgence. It is this change in her emotional stance-taking that allows for the emergence of public, active and collective engagement.

Such meanings are strengthened by the fact that the narrative does not assign blame to any specific, individual police officer. Rather, Anita's discourse consistently refers to the murder by means of passive constructions and undetermined subjects. She repeatedly ascribes agency to entities like "the system", causing the narrative to shift from an individual, concrete framework to a collective, abstract one. This happens, for instance, in the following excerpts:

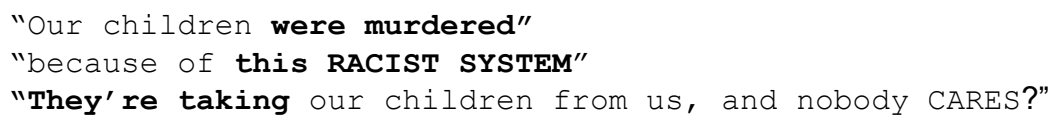

This reframing is enabled not only by lexical choices, but by the overall adoption of a particular narrative architecture, which organizes elements in a specific way:

(i) There is an opening statement, which introduces Anita, her son, and the reason why she is there (lines 1 to 4 );

(ii) This is followed by a political contextualization, in which Anita describes and decries widespread racism and police brutality in Rio de Janeiro's favelas (lines 5 to 12$)$;

(iii) In the complicating action, she briefly moves back to her individual story (lines 13 to 14$)$;

(iv) Finally, an evaluative coda re-emphasizes a more collective dimension (lines 14 to 16$)$.

The spiraling structure of Anita's narrative re-signifies her own story as more than a private episode. Her narration joins the broader narrative of a social movement, where, aligned with other, similar stories, it becomes an instrument to denounce the existence of a systemic crime.

An analogous discursive movement can be found in other narratives from the movement, such as the one produced by Jéssica, Paulo Ricardo's mother. As she tells her story during a demonstration, she emphasizes that 


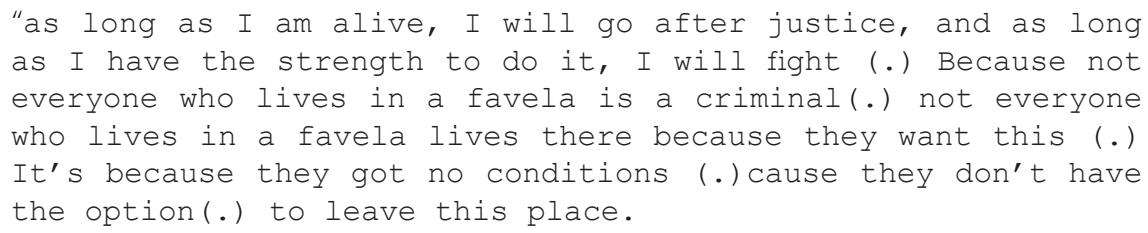

Once again, grief itself is reconfigured as a form of resistance against the extermination of black, young favela residents. The overarching structure of the narrative points to a coherence system according to which every life matters and the State must be held accountable for every death.

\section{FINAL REMARKS}

This paper explored how the mothers of victims of police violence engage in social movements like the Rede de Comunidades e Movimentos contra a Violencia. Our investigation was centered on a narrative fragment which can be seen as representative of our corpus: a speech delivered during a public demonstration in front of the Prosecution Office building. The narrator was Anita, a woman whose 19-year-old son had been fatally shot by an UPP police officer in the favela where he lived. Our analysis of Anita's narrative was informed by the principles of Narrative Analysis. In particular, we focused on the narrative's constitutive elements (LABOV, 1972), on the coherence systems it indexed (LINDE, 1993), and on how narratives tend to actualize emotional grammars (REZENDE \& COELHO, 2015). Our analysis was also underpinned by the sociological notion of moral shock (JASPER, 1997).

Our findings suggest that, in the social demonstrations organized by the Rede, as well as in mothers' own narratives, emotion plays a major performative role. The pain of grief-at once narrated and embodied in mothers' performancesbolsters resistance against the invisibilization, or the banalization, of young people's murders. It is worth noting that, by and large, deaths like these are swiftly turned into statistics by the media, or absorbed by hegemonic, oversimplified discourses which claim that "if they died, they must have done something wrong", or that "a good criminal is a dead criminal". If, as argued by Souza (2009), to re-exist is to cause crystallized discourses to quake, then these mothers re-exist by introducing their own repetitions. The same plot reoccurs, with different characters each time; the same episodes are narrated again and again. Categories like "mother" and "child", evoked to the point of exhaustion, recast lives like João's as meaningful and grievable. 
There is also a noteworthy dynamics in terms of how emotions are narratively deployed. The pain of grief-culturally understood as private-spirals into insurgence, which, in turn, catalyzes collective mobilization. In this process, two discursive mechanisms were seen as fundamental. First, events around the death of their children were rationalized and a series of causalities were introduced which generated overall coherence. The narrator operated with a coherence system that constructed João's murder as the corollary of structural racism, necropolitics, public security policies based on head-on confrontation, and of a putative "war on drugs" which is actually a "war on the poor". The second discursive mechanism is extrapolation: the individual experience of losing a child is reframed as a collective experience of suffering for the black and poor communities targeted not by occasional episodes of police brutality, but by a systemic genocidal policy.

Mothers vehemently challenge the discourse which represents these deaths as isolated cases in which state agents resorted to undue violence. Swaying between public and private, they amplify an alternative version which situates their individual stories in relation to a broader public security system: one which, under the guise of "self-defense", authorizes racism and promotes the widespread extermination of black populations. As these women claim their own space in the public realm, their stories gain more visibility, and they demand that institutions such as the Prosecution Office bring about relevant change.

We have called these stories "narratives of resistance" (EWICK; SILBEY, 2003). It is our understanding that they actively dispute the long-standing racist discourses and practices which structure police and judicial work, demanding that the State introduce effective, transformative measures. The circulation of such narratives in public spaces and social media may help other activists, as well as the family members of those victimized by police brutality, to join the fight for justice.

\section{REFERÊNCIAS}

BASTOS, L. C. (2005). Contando estórias em contextos espontâneos e institucionais uma introdução ao estudo da narrativa. Calidoscópio. vol. 3, n. 2, p. 74-87.

BASTOS, L. C. \& BIAR, L. (2015). Análise de narrativa e práticas de entendimento da vida social. DELTA - Documentação e Estudos em Linguística Teórica e Aplicada, vol. 31.

BAUMAN, R. (1986). Story, Performance, and Event: Contextual Studies of Oral Narrative. Cambridge: Cambridge University Press. 
BRUNER, J. (1990). Atos de significação. Porto Alegre: Artes Médicas, 1997.

BUTLER. J. (2009) Quadros de Guerra: quando a vida é passível de luto? $1^{\text {a }}$ ed. Rio de Janeiro: Civilização Brasileira, 2015.

BUTLER. J. (2020). De quem são as vidas consideradas choráveis em nosso mundo público? . El País, 10jul. 2020. Disponível em: https://brasil.elpais.com/babelia/2020-07-10/ judith-butler-de-quem-sao-as-vidas-consideradas-choraveis-em-nosso-mundopublico.html Acesso em: 30 jul. 2020.

CERQUEIRA, D. et al. (2017). Atlas da violência - 2017. Rio de Janeiro: IPEA; São Paulo: FBSP. Disponível: http://www.ipea.gov.br/atlasviolencia/download/2/atlas-2017

DENZIN, N.; LINCOLN, Y. (2006). A disciplina e a prática da pesquisa qualitativa. In: Denzin, N.; Lincoln, Y. O planejamento da pesquisa qualitativa: teorias e abordagens. Porto Alegre: Artmed.

EWICK, P. SILBEY, S. (2003). Narrating Social Structure: Stories of Resistance to Legal Authority. AJS v. 108, n6 (may 2003), 1328-72, Chicago.

FACCHINI, R. SÍVORI, H. (2017). Dossiê Conservadorismo, Direitos, Moralidades e Violência: situando um conjunto de reflexões a partir da Antropologia. Cad. Pagu n.50, Campinas, Epub June 26.

FREIRE, J. 2011. Quando as emoções dão formas às reivindicações. In: Coelho, M. C. e Rezende, C. B. (orgs.) Cultura e Sentimentos - Ensaios em antropologia das emoções. Rio de Janeiro: FAPERJ, pp. 168-196.

GEORGAKOPOLOU, A. 2006. Thinking big with small stories in narrative and identity analysis. Narrative Inquiry, v.16, n.1, p.122-130.

GOMES, N. L. (2012). Alguns Termos E Conceitos Presentes No Debate Sobre Relações Raciais No Brasil: Uma Breve Discussão. Revista Educação e Sociedade. V.33, nº 120 jul-set.

GONZALEZ, L. (1982) O Movimento Negro na última década. In Gonzalez, L. e Hasenbalg, C. Lugar de Negro. Rio de Janeiro: Marco Zero.

JASPER, J. (1997). The Art of Moral Protest: Culture, Biography, and Creativity in social Movements. Chicago: Chicago University Press. 
KILOMBA, G. (2008). Memórias da Plantação: Episódios de Racismo cotidiano. Trad. Jess Oliveira. Rio de Janeiro: Cobogó, 2019.

LABOV, W. (1972). The transformation of experience in narrative syntax. In: Language in the inner city. Philadelphia: University of Pennsylvania Press.

LINDE, C. (1993). Life Stories: the creation of conference. NY: Oxford University Press.

LODER, L.L. (2008). O modelo Jefferson de transcrição: convenções e debates. In: L.L. Loder; N.M. Jung (org.) Fala-em-interação social: introdução à análise da conversa etnometodológica. São Paulo: Mercado de Letras, p. 127-161.

MBEMBE, A. (2018). Necropolítica. São Paulo: N-1 Edições.

MELUCCI. A. (2001). A invenção do presente; Movimentos sociais nas sociedades complexas. Petrópolis: Vozes.

MISSE, M, (org.) (2011). "Autos de Resistência": uma análise dos homicídios cometidos por policiais na cidade do Rio de Janeiro (2001-2011)". Relatório Final de Pesquisa Núcleo de Estudos da Cidadania, Conflitos e Violência Urbana. Universidade Federal do Rio de Janeiro: Mimeo.

MOITA LOPES, L.P. (2001). Práticas narrativas como espaço de construção das identidades sociais: uma abordagem socioconstrucionista. In: Ribeiro, Lima e Lopes Dantas (orgs.). Narrativa, Identidade e Clínica. Rio de Janeiro: IPUB.

NASCIMENTO, A. do. (1978). O genocídio do negro brasileiro: processo de um racismo mascarado. Rio de Janeiro: Paz e Terra.

NASCIMENTO A. A. Do; GRILlO, C.C.; NERI, N. E. (2009). Autos com ou sem resistência: Uma análise dos inquéritos de homicídios cometidos por policiais. $33^{\circ}$ Encontro Anual da ANPOCS - Anais. Disponível em:https://anpocs.com/index.php/ papers-33-encontro/gt-28/gt08-24/1843-andreanascimento-autos/file

POLLETTA, F; JASPER J. M. (2001). Collective Identity and Social Movements. Annual Review of Sociology; 27: 283-305.

REZENDE, C. B. e COELHO, M. C. (2015). Antropologia das Emoções. Rio de Janeiro: Editora FGV, $2^{\text {a }}$ reimpressão.

SANTIAGO, V.W.B. (2016). A luta das mães nas favelas: margens, Estado e resistência. Dissertação (Mestrado) - Pontifícia Universidade Católica do Rio de Janeiro. Rio de Janeiro. 
SARBIN, T. R. (2001). Embodiment and the Narrative Structure of Emotional Life. Narrative Inquiry, 11 (1), 217-225, Amsterdam.

SCHERERWARREN, I. (1999). Cidadania sem fronteiras: ações coletivas na era da globalização. São Paulo: Hucitec.

SINHORETTO, J. e MORAIS, D. de S. (2018). "Violência e racismo: novas faces de uma afinidade reiterada". Revista de Estudios Sociales 64: 15-26. https://doi.org/10.7440/ res64.2018.02

SOUZA, A. L. S. (2009). Letramentos de Reexistência: culturas e identidades no movimento bip-bop. Tese (doutorado) - Universidade Estadual de Campinas, Instituto de Estudos da Linguagem. Campinas, SP: [s.n.].

TANNEN, D. (1989). Talking Voices: Repetition, Dialogue, and Imagery in Conversational Discourse. New York: Cambridge University Press.

TELLES, E. (2004). Race in Another America: The Significance of Skin Color in Brazil. Princeton; Oxford: Princeton University Press.

TOURAINE, A. Pensar outramente. Petrópolis: Vozes, 2007.

THOMPSON, R. A. (1990). Emotion and self-regulation. In Thompson, R. A. (Ed.) Socioemotional development. Nebraska Symposium on Motivation. Lincoln, NE: University of Nebraska Press, Vol. 36 (pp. 367-467).

WINANT, H. (2001). The world is a ghetto: Race and Democracy since World War II. New York: Basic Books. 


\section{APPENDIX}

Original data (Portuguese)

Anita:

"Meu nome é Anita, sou moradora da favela de Manguinhos eu sou a mãe de João da Silva. Para alguns de vocês aqui, pode parecer que vocês estão ouvindo a mesma história a todo momento, mas é isso que acontece, nossos filhos foram assassinados, por causa desse sistema RACISTA. Que diz que moradores de favelas (1s) Jovens (1s) Negros (1s) Pobres, moradores de periferias, TEM que ser ASSASSINADOS. Não vem com esse discurso de que "ah o combate às drogas", na verdade não é isso. Nós, que moramos em favelas, que perdemos nossos filhos INJUSTAMENTE sabemos que o que há é o combate aos pobres. Estão tirando os nossos filhos, e ninguém SE IMPORTA? (3s) o MEU FILHO, ele foi assassinado aos dezenove anos de idade com um tiro nas costas, totalmente indefeso. E é por isso que eu tô aqui hoje. junto com essas mães, com esses pais, com esses familiares".

\section{Cida:}

[...]"tava desempregado, era negro (.) favelado (.) uma passagem (.) em bangu, né porque ((inaudível)) quando a UPP entrou no final, no final de (.) dois mil e onze né (.) começaram a implicância com ele (.) já tinha visto os documentos que ele tinha uma passagem(.) foi isso que o ESTADO entrou pra DENTRO da favela pra fazer (.) porque em ipanema, copacabana os brancos faz PLANTAÇÃO de maconha dentro de belíssimos apartamentos, e NÃO ACONTECE NADA, o Higor era usuário de dentro da favela".

Jéssica:

enquanto eu tiver vida, eu vou atrás dessa justiça, e: enquanto eu tiver força pra isso eu vou lutar (.), porque: nem todo mundo que mora em comunidade é marginal, (.) nem todo mundo que mora em comunidade mora porque quer, (.) é por não ter condições. (.) é por não ter opção, (.) de sair de lá.

Recebido: $12 / 9 / 2020$

Aceito: 17/11/2020

Publicado: 23/11/2020 